\title{
Positive effects of Green Tea on hepatic dysfunction, lipid peroxidation and antioxidant defence depletion induced by cadmium
}

\author{
KHALED HAMDEN, SERGE CARREAU ${ }^{\mathrm{a}}$, FATMA AYADI MARKI ${ }^{\mathrm{b}}$, \\ HATEM MASMOUDI ${ }^{\mathrm{C}}$ and ABDELFATTAH EL FEKI*
}

Animal Ecophysiology, Faculty of Sciences, Sfax, Tunisia

${ }^{a}$ USC 2006 INRA- EA 2608, Biochemistry-University of Caen, France

${ }^{\mathrm{b}}$ Biochemistry laboratory, CHU H. Bourguiba, Sfax, Tunisia

c Immunology laboratory, CHU H. Bourguiba, Sfax, Tunisia

\begin{abstract}
Cadmium (Cd) is a highly toxic environmental and industrial cumulative pollutant that affects many organs, especially the liver. The present study was designed to evaluate the antioxidant effect of green tea on cadmium-induced hepatic dysfunction and oxidative stress in rats. Adult male Wistar rats were administered cadmium by injection of $20 \mu$ moles $/ \mathrm{kg}$ bw/ every 3 days for six months. This study revealed significant ( $\mathrm{p}<$ $0.05)$ liver dysfunction, lipid peroxidation and a decline in antioxidant enzyme activities in the liver of cadmium-treated rats compared to control animals. Compared to control rats, the activities of lactate dehydrogenase (LDH), gammaglutamyl transferase (GGT), acid phosphatase (PAC), phosphatase alkaline (PAL), as well as bilirubin and thiobarbituric acid-reactive substances (TBARs), were significantly $(\mathrm{p}<0.05)$ increased in Cd-treated rats. Moreover, antioxidant enzyme activities, such as superoxide dismutase (SOD), glutathione peroxidase (GPX) and catalase, were significantly $(\mathrm{p}<0.05)$ decreased in the liver of cadmiumtreated rats. The oral administration of $5 \%$ aqueous green tea extract, along with cadmium treatment for six months, caused a significant $(\mathrm{p}<0.05)$ improvement in cadmium-induced toxicity by significantly decreasing $(\mathrm{p}<0.05)$ the activities of enzymatic markers of liver dysfunction (LDH, GGT, PAC, PAL activities, as well as the bilirubin rate). Indeed, green tea extract significantly increased $(\mathrm{p}<0.05)$ antioxidant enzymatic activities (SOD, Catalase, GPX) in rat liver, compared to those given cadmium alone. Thus, the oral administration of green tea, along with cadmium significantly $(\mathrm{p}<0.05)$ improves cadmium-induced liver dysfunction and stress oxidant in rats' liver.
\end{abstract}

Key terms: cadmium; rat liver dysfunction; green tea, antioxidant enzymes, lipid peroxidation.

\section{INTRODUCTION}

Cadmium $(\mathrm{Cd})$ is a heavy metal with great environmental health effects and all $\mathrm{Cd}$ compounds have been classified as human carcinogens (Newairy et al, 2007). Cadmium is used industrially to manufacture electro-plates, batteries, alloys and fuels (Waisberg et al., 2003). The increasing industrial use of $\mathrm{Cd}$ causes soil, air and water contamination. Exposure to cadmium is associated with liver tumors and toxicity (Vicente-Sánchez et al., 2008). Various studies have shown that cadmium toxicity in liver seems to be crucially mediated by the production of reactive oxygen species known to induce necrosis in various rat organs (Razinger et al., 2008; Hsu et al., 2007), lipid peroxidation (Borges et al., 2008) and a decrease in

ABREVIATIONS: LDH, lactate dehydrogenase; GGT, gammaglutamyl transferase; PAC, acid phosphatase; PAL, phosphatase alkaline; TBARS, thiobarbituric acid-reactive substances; SOD, superoxide dimutase; GPX, glutathione peroxidase.

Correspondence to: Dr: Khaled HAMDEN, Lab. of Animal Ecophysiology, Fac. of Sciences, PB 802, 3018 , Sfax,University of Sfax, TUNISIA, Email: hamdenkhalid@yahoo.com, Phone: (+216) 97469 111, Fax: (+216) 74274437 
antioxidant enzymes (El-Sharaky et al., 2007).

Epidemiological studies have strongly suggested that diet plays an important role in the prevention of chronic diseases (LopezAlarcon et al., 2007). Polyphenolics, commonly found in fruits, vegetables and grains, provide chemoprotective effects to combat oxidative stress in the body and to maintain balance between oxidants and antioxidants in order to improve human health (Hsu, 2006). An imbalance caused by oxidant excess leads to oxidative stress, resulting in DNA and protein damages and increases the risk of degenerative diseases such as cancer (Hsu, 2006). Green tea is prepared from the tea plant Camellia sinensis. The predominant flavonoids in green tea are catechins, namely epicatechin (EC), epicatechin-3-gallate (ECG), epigallocatechin (EGC), and epigallocatechin-3- gallate (EGCG) (Feng, 2006). These compounds account for up to $30-40 \%$ of the dry weight of green tea (Balentine et al, 1997). From a pharmacological perspective, EGCG has currently received the most attention by far due to its anti-oxidant, anti-inflammatory, and anti-carcinogenic effects (Shankar et al, 2007; Tipoe et al, 2007).

The present study was designed to assess the protective effect of green tea (GT) infusion by evaluating the free radicals scavenging capacity using the DPPH and $\mathrm{NBT} /$ riboflavin in vitro. In vivo, the present paper was carried out to study the effect of green tea infusion on hepatic toxicity assessed by lipid peroxidation, enzymatic antioxidants and cell damage biomarkers in rat livers intoxicated by cadmium.

\section{MATERIALS AND METHODS}

\section{Animals and treatments}

Adult male Wistar rats weighing approximately 140-152g were obtained from the central pharmacy, Tunisia. They were provided with animal feed and water ad-libitum and maintained in $12 \mathrm{~h}$ light/dark cycles at $24 \pm 4^{\circ} \mathrm{C}$. Animals were divided into four groups (six rats per group) and caged separately. Group 1 (untreated control) animals was injected subcutaneously with $0.9 \%$. $\mathrm{NaCl}$. Group 2 (group Cd) was injected sub-cutaneously with $20 \mu$ moles of cadmium/kg bw/ every 3 days and applied during six months (Wallkes et al., 2000). Group 3 (group Cd + GT) was treated with cadmium and given $5 \%$ green tea extract instead of drinking water for 12 hours daily during six months. Group 4 (Group GT) was given only 5\% tea for 12 hours daily. On completion of the treatments, the animals were decapitated and the arterio-venous blood collected. After centrifugation of the blood at $1000 \mathrm{~g}$, $4^{\circ} \mathrm{C}$, the liver parameters ( $\mathrm{LDH}$, acid phosphatase, gamma-glutamyl transferase, phosphatase alkaline activities and bilirubin rate) were determined in the serum. The antioxidant enzymes activities (SOD, catalase and GPX) and the TBARs were determined in the liver extracts.

\section{Preparation of green tea extract}

Green tea was extracted using the method described elsewhere (Itharat et al., 2004) and modified in our laboratory. Briefly, the plant samples weighing about $50 \mathrm{~g}$ were individually extracted in 1 litre at $40^{\circ} \mathrm{C}$ for $60 \mathrm{~min}$. After filtration, the extract was kept at $4^{\circ} \mathrm{C}$, prepared and given each day.

For DPPH and NBT/Riboflavin tests, the aqueous extract was prepared as previously described elsewhere (Sharma et al, 2007). Briefly, green tea was collected locally and air dried, powdered and extracted with double distilled water by refluxing for $36 \mathrm{hr}$ $(12 \times 3)$ at $80^{\circ} \mathrm{C}$. The extract thus obtained was vacuum evaporated so as to make it into powder form. The extract was redissolved in double-distilled water just before analysis.

\section{$D P P H$ radical scavenging}

The assay described by Ohinishi et al., (1994) was used to determine DPPH radical scavenging. One milliliter of DPPH solution (0.1 $\mathrm{mM}$ in ethanol) was mixed with $1 \mathrm{ml}$ of green tea with $(0-248 \mu \mathrm{g} / \mathrm{ml})$ and reacted for $30 \mathrm{~min}$, before mixture absorbance was measured at $517 \mathrm{~nm}$ against $95 \%$ ethanol 
solution as the blank. Triplicate measurements were performed and the antioxidant activity was expressed as the percentage of scavenged DPPH: Scavenging effect $(\%)=\left[\left(A_{0}-A_{l}\right) / A_{0}\right] \times 100$ where A0 and $\mathrm{A} 1$ are the absorbance for the blank and in the presence of green tea respectively.

\section{NBT (superoxide scavenging) assay}

The inhibition of superoxide radical production was evaluated using the nitroblue tetrazolium NBT.reduction method of McCord and Fridovic (1969). The reaction mixture contained: EDTA (6M), riboflavin $(2 \mu \mathrm{M})$, NBT $(50 \mu \mathrm{M})$, green tea extract (from 10 to $248 \mu \mathrm{g} / \mathrm{ml}$ ) and phosphate buffer and phosphate buffer (67 mM, pH 7.8) in a final volume of $3 \mathrm{ml}$. The tubes were uniformly illuminated with an incandescent lamp for $15 \mathrm{~min}$, and the optical density was measured at $530 \mathrm{~nm}$ before and after illumination.

\section{Estimation of lipid peroxidation}

Lipid peroxidation in the liver and kidney was estimated colorimetrically by measuring thiobarbituric acid reactive substances (TBARS) using the methods of Buege and Aust (1984). In brief, $0.1 \mathrm{ml}$ of tissue homogenate was treated with $2 \mathrm{ml}$ of TBA-trichloroacetic acid-HCl reagent $(0.37 \% \mathrm{TBA}, 0.25 \mathrm{MHCl}$ and $15 \% \mathrm{TCA}$, $1: 1: 1$ ratio), placed for $15 \mathrm{~min}$ in a water bath and then cooled and centrifuged at $3500 \times \mathrm{g}$ for $10 \mathrm{~min}$ at room temperature. The absorbance of supernatant was measured at $535 \mathrm{~nm}$ against a reference blank. Values were expressed as $\mathrm{mM} / \mathrm{mg}$ protein.

\section{Estimation of catalase activity}

Catalase (CAT) was estimated by the method of Aebi (1984). The reaction mixture contained $1.0 \mathrm{ml}$ of $0.01 \mathrm{M}$ phosphate buffer ( $\mathrm{pH} 7.0), 0.1 \mathrm{ml}$ of tissue homogenate and $0.4 \mathrm{ml}$ of $50 \mathrm{M} \mathrm{H} 2 \mathrm{O} 2$. The reaction was stopped by the addition of 2.0 $\mathrm{ml}$ of dichromate-acetic acid reagent $(5 \%$ potassium dichromate and glacial acetic acid were mixed in 1:3 ratio). Then the absorbance was read at $620 \mathrm{~nm}$; CAT activity was expressed as $\mu \mathrm{M}$ of $\mathrm{H} 2 \mathrm{O} 2$ consumed $/ \mathrm{min} / \mathrm{mg}$ protein.

\section{Estimation of superoxide dismutase activity}

SOD was assayed according to the technique of Marklund and Marklund (1975) based on the inhibition of the formation of nicotinamide adenine dinucleotide, phenazine methosulfate, and amino blue tetrazolium formazan. A single unit of enzyme was expressed as $50 \%$ inhibition of nitroblue tetrazolium reduction per $\mathrm{min} / \mathrm{mg}$ protein.

\section{Estimation of gluthatione peroxidase activity}

GPx activity was measured by the method described by Pagila and Valentine (1967). Briefly, the reaction mixture contained 0.2 $\mathrm{mL}$ of $0.4 \mathrm{M}$ phosphate buffer $(\mathrm{pH} 7.0), 0.1$ $\mathrm{mL}$ of $10 \mathrm{mM}$ sodium azide, $0.2 \mathrm{~mL}$ of tissue homogenate (supernatant; homogenized in 0.4 $\mathrm{M}$ phosphatebuffer, $\mathrm{pH}$ 7.0), $0.2 \mathrm{~mL}$ of GSH, and $0.1 \mathrm{~mL}$ of $0.2 \mathrm{mM}$ hydrogen peroxide. The contents were incubated at $37^{\circ} \mathrm{C}$ for 10 min. The reaction was stopped by adding 0.4 $\mathrm{mL}$ of $10 \%$ TCA and centrifuged.

\section{Estimation of protein level}

The amount of proteins was determined by the method of Lowry et al (1951) using bovine serum albumin as the standard at $660 \mathrm{~nm}$.

Estimation of LDH, GGT, PAC and PAL activities and bilirubin level

The activities of lactate dehydrogenase (LDH), gamma-glutamyl transferase (GGT), acid phosphatase (PAC), phosphatase alkaline (PAL), and bilirubin were assayed using commercial kits from Sigma (Munich, Germany) and Boehringer (Mannheim, Germany).

\section{Statistical analysis}

Data are presented as means \pm SEM. The determinations were performed from 6 
animals per group and the differences were examined by the one-way analysis of variance (ANOVA) followed by the Fisher test (Stat View) and the significance was accepted at $\mathrm{p}<0.05$.

\section{RESULTS}

Radicals scavenging activity on DPPH and NBT (Fig 1)

In vitro, the antioxidant activity of green tea infusion was evaluated by its ability to scavenge DPPH and NBT free radicals. GT extract showed a scavenging activity with a percentage decrease, versus the absorbance of DPPH and NBT standard solution of $92 \%$ and $91 \%$, respectively at a concentration of 32 and $124 \mu \mathrm{g} / \mathrm{ml}$, respectively.

LDH, PAC, GGT, and PAL activities in serum (Fig 2)

The activities of LDH, PAC, GGT and PAL of rats at month 6 after giving cadmium were obviously higher than the levels in the control (by 35, 55, 421, and 66\%, respectively). In rats that received at the same time cadmium and GT infusion, the activities of all the enzymes increased but remained lower than those in rats that received only cadmium (by 22\%, 29\%, $22 \%$, and $35 \%$ respectively).

\section{Bilirubin level (Fig 3)}

The bilirubin concentration increased by $137 \%$ in the serum of rats that received $\mathrm{Cd}$. In the rats that received $\mathrm{Cd}$ plus green tea extract, protective effects were observed by maintaining bilirubin rate lower by $36 \%$ compared to the rats that received only $\mathrm{Cd}$.

SOD, Catalase, and GPX activities in liver (Fig 4)

The liver activities of SOD, catalase, and GPX decreased as a result of $\mathrm{Cd}$ administration (by 63, 47, and 29\% respectively) compared to control rats. In the rats that received at the same time $\mathrm{Cd}$ and green tea extract a protective effect was observed. The antioxidant enzymes activities were higher (by 129,55 , and $15 \%$ respectively) compared to rats that received only Cd.

\section{TBARs rate (Fig 5)}

Lipid peroxidation is a potential mechanism of cell injury. TBARs concentration increased by $126 \%$ in liver after six months of treatment with $\mathrm{Cd}$ compared to control animals. A protective effect of green tea against the $\mathrm{Cd}$-induced oxidative effects was observed. In fact, the TBARs concentration in the liver of rats that received $\mathrm{Cd}$ and green tea at the same time was lower by $44 \%$.

\section{DISCUSSION}

Cadmium, a heavy metal, is among the elements which are present in soils, sediments, air and water as a result of its numerous industrial uses (Razinger et al., 2008). The classification of cadmium as a human and animal toxic substance (ElSharaky et al., 2007; IRAC. 1993) in the liver is supported by strong evidence from animal experiments. In rodents, cadmiuminduced toxicity is seen in various organs, such as liver (Chater et al, 2008; VicenteSánchez et al., 2008). Various studies have shown that cadmium toxicity seems to be crucially mediated by the induction of cells damage in various rat organs consecutive to the production of reactive oxygen species (Kusakabe et al., 2008). Cadmium is known to induce the production of hydroxyl radicals (Badisa et al, 2007), superoxide anions, nitric oxide and hydrogen peroxide (Rodríguez-Serrano et al., 2006). It also increases the rates of lipid peroxidation in the liver (Borges et al., 2008) and decreases the antioxidant enzymes activities (ElSharaky et al., 2007).

The results of this paper have confirmed that chronic cadmium intoxication induces a decrease in SOD, catalase and GPX activities and an increase of the TBARs rate in hepatic tissues. The imbalance between antioxidant/oxidant induced by cadmium was also observed by other authors 

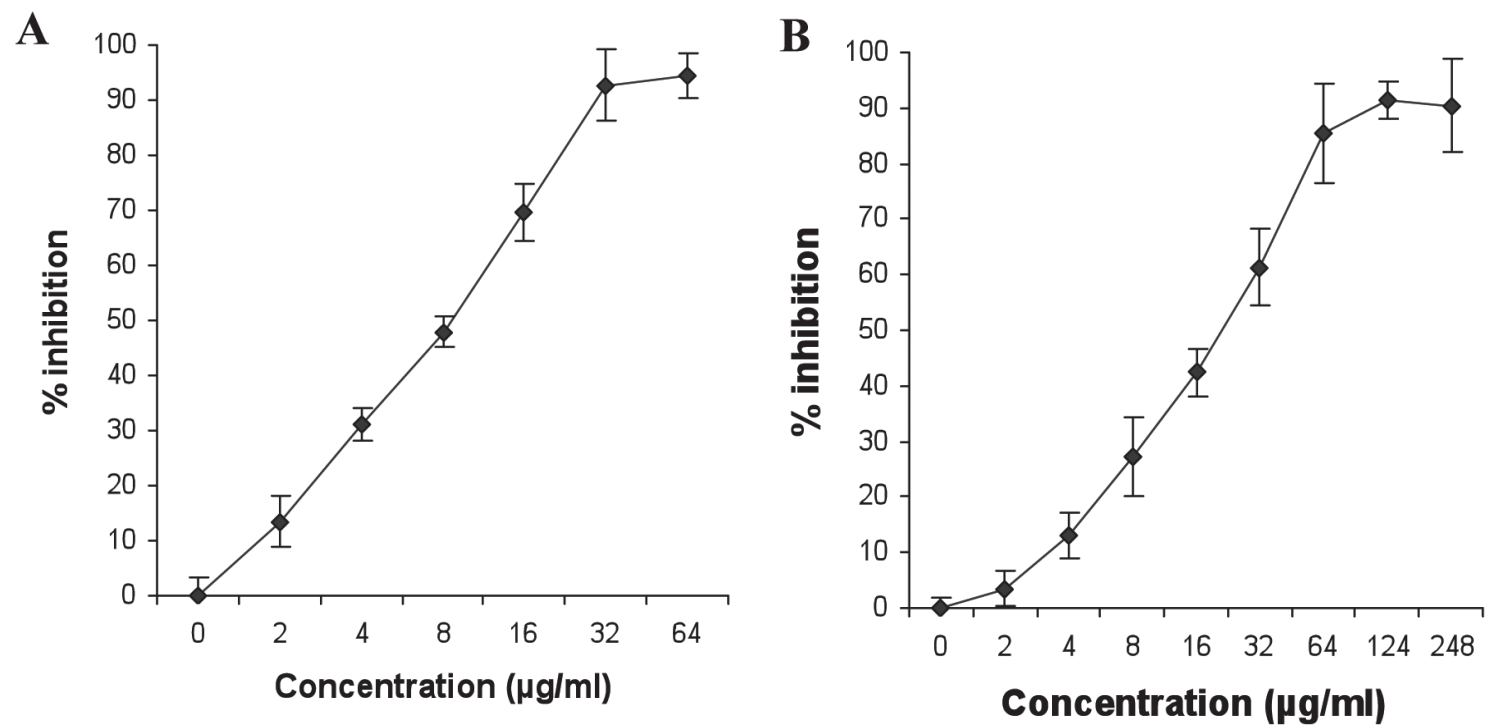

Figure 1: Free-radical and Superoxide scavenging activities of aqueous Green Tea extract are measured by using the DPPH (A) and NBT/Riboflavin (B) assays. N=3

(Eriyamremu et al, 2008), it causes an increase in hydroxyl radicals (Liu et al, 2008; O’Brien and Salacinski, 1998), superoxide anions, nitric oxide and hydrogen peroxide production (Liu et al, 2008; Chen et al, 2008; Hsu et al, 2007). The free radicals attack hepatic cells, leading to hepatic toxicity and dysfunction that are supported by the increase in $\mathrm{LDH}$, GGT, PAL and PAC activities (Jamshidzadeh et al, 2008; Selmanoglu et al, 2008; Zeashan et al, 2008).

The defence against long-term cadmium exposure consists of both antioxidants synthesized in the tissues and exogenous antioxidants supplied with diet. The present paper reveals that in animals intoxicated with cadmium, green tea partially prevents liver dysfunction and alterations of antioxidative parameters induced by cadmium. The protective effect of green tea is connected with its components that possess scavenging free radical properties demonstrated in this study by DPPH and $\mathrm{NBT} /$ riboflavin in vitro tests. Indeed, flavonoids existing in tea extract enhance the expression of intracellular endogenous antioxidants such as SOD, catalase and GPX by maintaining their activities higher compared to the control treated-rats $(\mathrm{Cd})$ and other antioxidants enzymes such as glutathione, glutathione reductase, glutathione-S-reductase, and quinone reductase (Hamden et al, 2008; Bolling et al, 2007). In fact, a direct genomic effect of tea flavonoids with estrogen responsive elements caused an induction of the enzyme antioxidant expression. (Vina et al.2005).

In addition, tea flavonoids might protect against toxicity in liver through the inhibition of oxidative damage. They serve as derivatives of conjugated ring structures and hydroxyl groups that have the potential to function as in vitro antioxidants by scavenging superoxide anion (Razali et al, 2008), singlet oxygen (Almeida et al, 2008), lipid peroxy-radicals (Hsu, 2006; Alejandro, 2000), and/or stabilizing free radicals involved in oxidative processes through hydrogenation or complexing with oxidizing species (Shahidi et al., 1992). Another mechanism proposed for protection against cancer by dietary flavonoids may include the induction of Phase II detoxification enzymes in cells. Modification of cellular detoxification enzymes could be a major mechanism for protection against the toxic effects (Moon et al, 2005; Liu et al, 2003; Kang et al, 2003). 

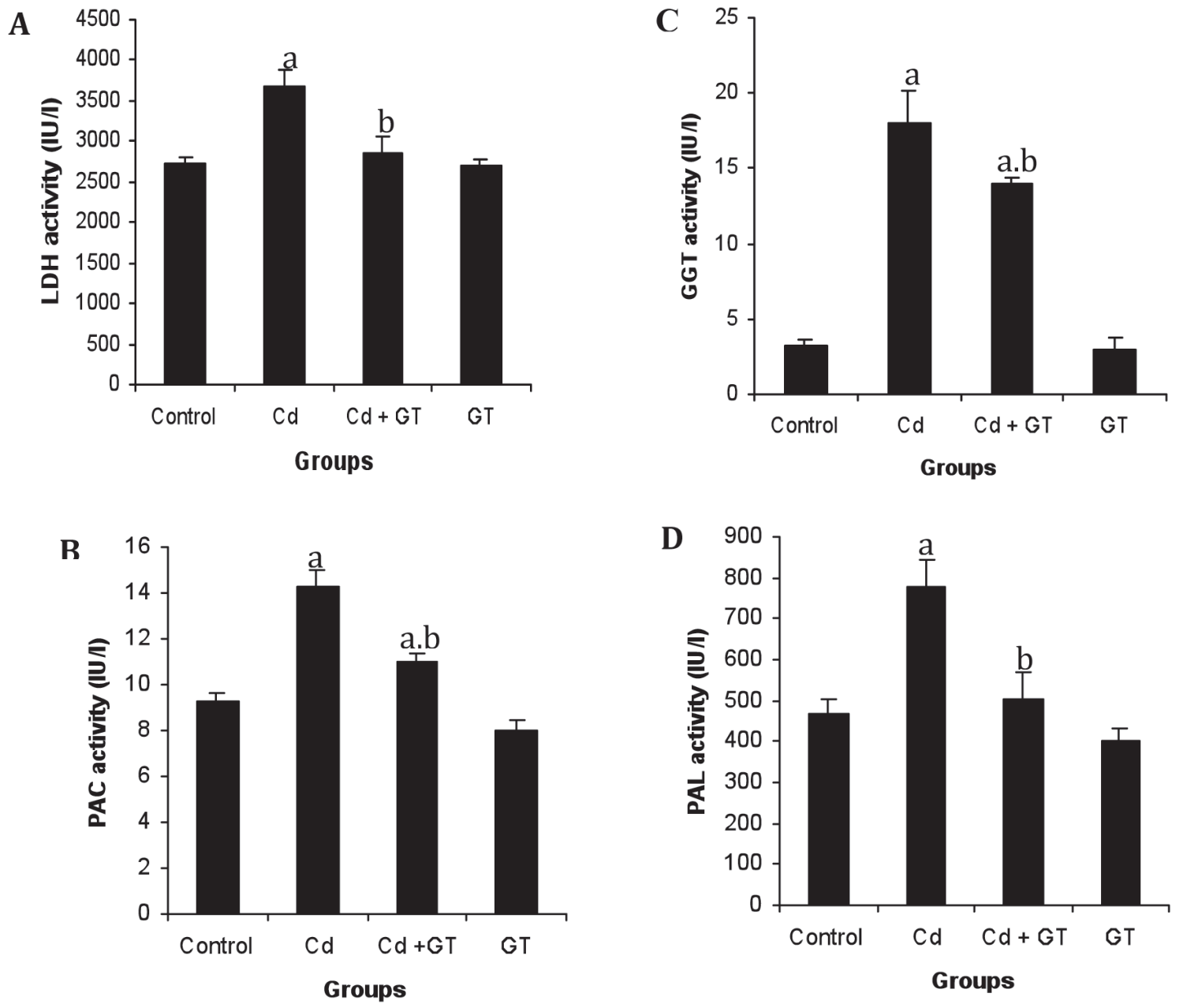

Figure 2: Effect of cadmium and Green Tea infusion on the LDH (2A), PAC (2B), GGT (2C), PAL (2D) activities. Values are mean \pm SEM; $n=6$. LDH, PAC, GGT, PAL- IU/1.

${ }^{\mathrm{a}}$ As compared to control group: $\mathrm{p}<0.05 .{ }^{\mathrm{b}}$ As compared to Cd group: $\mathrm{p}<0.05$

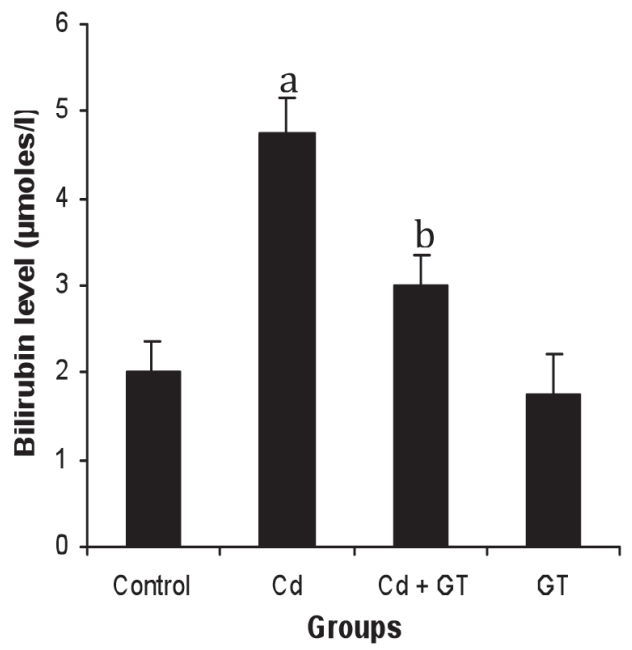

Figure 3: Effect of cadmium and Green Tea infusion on the bilirubin level. Values are mean \pm SEM; $\mathrm{n}=6$. Bilirubin- ' $\mu$ moles/l.

${ }^{\mathrm{a}}$ As compared to control group: $\mathrm{p}<0.05 .{ }^{\mathrm{b}}$ As compared to Cd group: $\mathrm{p}<0.05$ 


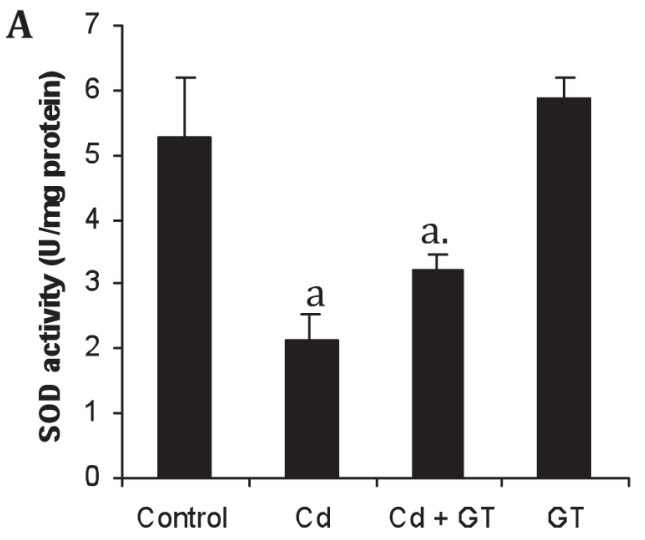

Groups

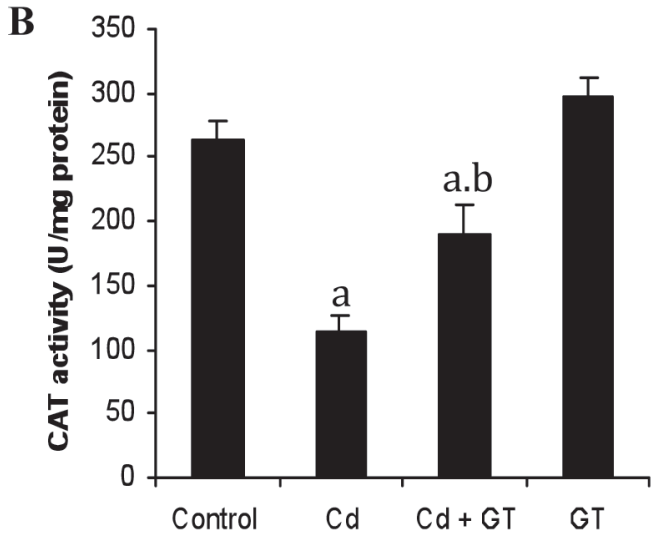

Groups

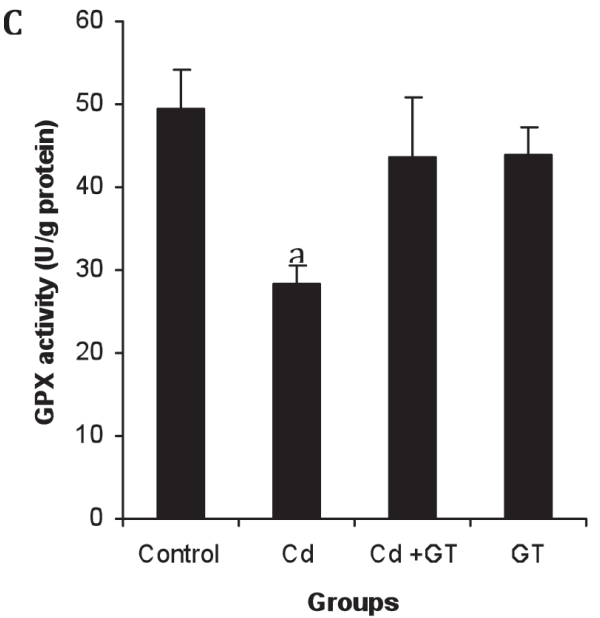

Figure 4: Effect of cadmium and Green Tea infusion on the hepatic SOD (4A), CAT (4B), and GPX (4C) activities. Values are mean \pm SEM; $n=6$. SOD activity-Units $/ \mathrm{min} / \mathrm{mg}$ protein. Catalase activity$\mu$ moles $\mathrm{H}_{2} \mathrm{O}_{2}$ consumed/mg protein/min. GPX activity- $\mu$ moles of GSH oxided/min/g protein. a As compared to control group: $\mathrm{p}<0.05$. ${ }^{\mathrm{b}}$ As compared to $\mathrm{Cd}$ group: $\mathrm{p}<0.05$

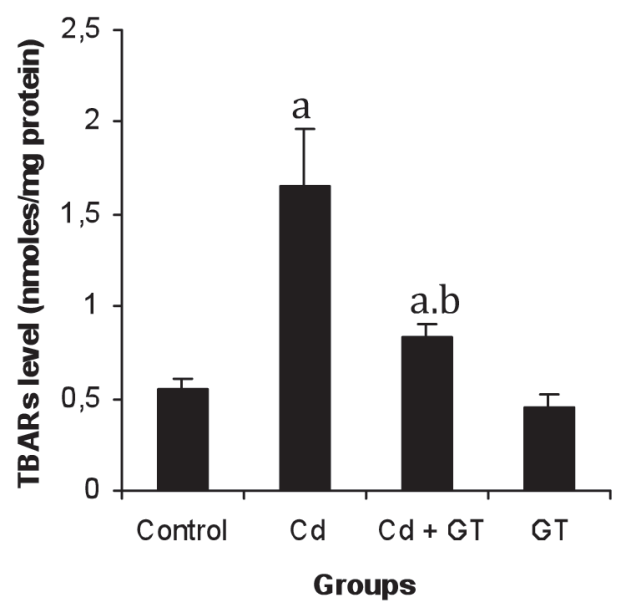

Figure 5: Effect of cadmium and Green Tea infusion on the hepatic TBARs rate. Values are mean \pm SEM $; n=6$. TBARs rate-nmoles TBARs/mg protein.

${ }^{a}$ As compared to control group: $\mathrm{p}<0.05 .{ }^{\mathrm{b}}$ As compared to Cd group: $\mathrm{p}<0.05$ 


\section{CONCLUSION}

It can be concluded that flavonoid-rich food may play a protective role against cadmium-mediated liver dysfunction and toxicity. Long-term administration with green tea inhibits lipid peroxidation and induces the activity of anti-oxidant enzymes, such as SOD, catalase, and GPX, consequently attenuating liver dysfunction by lowering increase of LDH, GGT, PAL, and PAC activities, as well as the bilirubin rate.

\section{ACKNOWLEDGEMENTS}

This work was supported by the Tunisian Ministry of Higher Education and Scientific Research and Technology and the Tunisian Ministry of Public Health. We extend our thanks to Mr. Hafedh Bjaoui, an English teacher at the Sfax Faculty of Sciences for having proofread this paper.

\section{REFERENCES}

AEBI H (1984) Catalase in vitro. Methods Enzymol 105: 121-26

ALEJANDRO DB, ANDREO G, SUSANA P (2000) Effect of nitric oxide and plant antioxidants on microsomal content of lipid radicals. Biol Res 33: 159-65

ALMEIDA IF, FERNANDES E, LIMA JLFC, COSTA PC, BAHIA MF (2008) Protective effect of Castanea sativa and Quercus robur leaf extracts against oxygen and nitrogen reactive species. J Photochem Photobiol B 91: $87-95$

BADISA VL, LATINWO LM, ODEWUMI CO, IKEDIOBI CO, BADISA RB, AYUK-TAKEM LT, NWOGA J, WEST J. (2007) Mechanism of DNA damage by cadmium and interplay of antioxidant enzymes and agents. Environ Toxicol 2: 144-51

BALENTINE DA, WISEMAN SA, BOUWENS LC (1997) The chemistry of tea flavonoids, Crit. Rev. Food Sci. Nutr 37: 693-704

BOLLING BW, CHEN E, PARKIN KL (2007) Quinone reductase inducing and antioxidant activities of aqueous isolates of green bean (Phaseolus vulgaris L.). Food Res Intern 40: 182-90

BORGES LP., BRANDAO R., GODOI B., NOGUEIRA CW., ZENI G (2008) Oral administration of diphenyl diselenide protects against cadmium-induced liver damage in rats. Chem Biol Interact 171: 15-25

BUEGE JA, AUST SD (1984) Microsomal lipid peroxidation. Methods Enzymol 105: 302-310

CHATER S, DOUKI T, GARREL C, FAVIER A, SAKLY M, ABDELMELEK H (2008) Cadmium-induced oxidative stress and DNA damage in kidney of pregnant female rats. CR. Biologies 331: 426-32

CHEN L, LIU L, HUANG S (2008) Cadmium activates the mitogen-activated protein kinase (MAPK) pathway via 3 induction of reactive oxygen species and inhibition of protein phosphatases $2 \mathrm{~A}$ and 5. Free Radic Biol Med, in press

EL-MARAGHY SA, GAD MZ, FAHIM AT, HAMDY MA (2001) Effect of cadmium and aluminum intake on the antioxidant status and lipid peroxidation in rat tissues. J. Biochem. Mol. Toxicol 15: 207-14

EL-SHARAKY AS., NEWAIRY AA., BADRELDEEN MM., EWEDA SM., SHEWEITA SA (2007) Protective role of selenium against renal toxicity induced by cadmium in rats. Toxicology 235: 185-193

ERIYAMREMU GE, OJIMOGHO SE, ASAGBA SO, OSAGIE VE (2008) Palm oil induced changes in ocular tissue lipid peroxidation, antioxidant enzymes and ATPases of rabbits in cadmium toxicity. Food Chem Toxicol, in press

ESPOSITO E, ROTILI D, DI MATTEO V, DI GIULIO C, CACCHIO M, ALGERI S (2002) A review of specific dietary antioxidants and the effects on biochemical mechanisms related to neurodegenerative processes. Neurobiol Aging 23: 719-735

FENG WY (2006) Metabolism of green tea catechins: an overview, Curr Drug Metab 7: 755-809

FUJIMAKI H, ISHIDO M, NOHARA K (2000) Induction of apoptosis in mouse thymocytes by cadmium. Toxicol. Lett 115: 99-105

HAMDEN K, SILANDRE D, DELALANDE C, ELFEKI A, CARREAU S. Protective effects of estrogens and caloric restriction during aging on various rat testis parameters. Asian J Androl 2008; 10: in press

HARTWIG A, SCHWERDTLE T (2002) Interactions by carcinogenic metal compounds with DNA repair processes: toxicological implications. Toxicol. Lett 127: $47-54$

HSU CY (2006) Antioxidant activity of extract from Polygonum aviculare L. Biol Res 39: 281-88

HSU CY, CHAN YP, CHANG J (2007) Antioxidant activity of extract from Polygonum cuspidatum. Biol Res 40: 13-21

HSU CY (2006) Antioxidant activity of extract from Polygonum aviculare L. Biol Res 39: 281-88

HSU CY, CHAN YP, CHANG J (2007) Antioxidant activity of extract from Polygonum cuspidatum. Biol Res 40: 13-21

International Agency for Research on Cancer (IARC) (1993) Beryllium, Cadmium, Mercury, and Exposures in the Glass Manufacturing Industry, Monographs on the Evaluation of Carcinogenic Risk to Humans, vol. 58, IARC, Lyon, France. 119-238

ITHARAT A, HOUGHTON PJ, ENO-AMOOQUAYE E, BURKE PJ, SAMPSON, JH, RAMAN A.(2004) In vitro cytotoxic activity of Thai medicinal plants used traditionally to treat cancer. J Ethnopharmacol 90: 33-8

JUNG YD, ELLIS, LM (2001) Inhibition of tumour invasion and angiogenesis by epigallocatechin gallate (EGCG), a major component of green tea. Int. J Exp Pathol 82: 309-16

KANG, KW, PARK EY, KIM SG (2003) Activation of CCAAT/enhancer-binding protein beta by 20 -amino30-methoxyflavone (PD98059) leads to the induction of glutathione S- transferase A2.Carcinogenesis 24: $475-82$

KONDOH M, ARARAGI, S, SATO K, HIGASHIMOTO M, TAKIGUCHI M, SATO M. (2002) Cadmium induces apoptosis partly via caspase- 9 activation in HL-60 cells. Toxicology 170: 111-17

KUSAKABE T, NAKAJIMA K, NAKAZATO K, SUZUKI K, TAKADA H, SATOH T, OIKAWA M, ARAKAWA K, NAGAMINE T (2008) Changes of heavy metal, 
metallothionein and heat shock proteins in Sertoli cells induced by cadmium exposure. Toxicol In Vitro xxx: $\mathrm{XXX}-\mathrm{XX}$

LIU J, QIAN SY, GUO Q, JIANG J, WAALKES MP, MASON RP, KADIISKA MB (2008) Cadmium generates reactive oxygen- and carbon-centered radical species in rats: Insights from in vivo spin-trapping studies. Free Radic Biol Med 45: 475-81

LIU TT, LIANG NS, LI Y, YANG F, LU Y, MENG ZQ, ZHANG LS (2003) Effects of long-term tea polyphenols consumption on hepatic microsomal drugmetabolizing enzymes and liver function in Wistar rats. World J. Gastroenterol 9: 2742-44

LÓPEZ-ALARCÓN C, SPEISKY H, LISSI E (2007) Antioxidant effect of 5-amino salicylic acid on coppermediated LDL oxidation. Biol Res 40: 155-162

LOWRY OH, ROSEBROUGH NJ, FARR AL, RANDALL RJ (1951) Protein measurement with Folin phenol reagent. J Biol Chem 193: 265-275

LU J, JIN T, NORDBERG G, NORDBERG M (2005) Metallothionein gene expression in peripheral lymphocytes and renal dysfunction in a population environmentally exposed to cadmium Toxicol Appl Pharmacol 206: 150-6

MARKLUND S, MARKLUND G (1975) Involvement of the superoxide anion radical in the autoxidation of pyrogallol and convenient assay for superoxide dismutase. Eur J Biochem 47: 469-74

MCCORD JM, FRIDOVICH I (1969) Superoxide dismutase: an enzymatic function of erythrocuprein. $\mathbf{J}$ Biol Chem 244: 6049-55

MOON YJ, WANG X, MORRIS ME (2006) Dietary flavonoids: Effects on xenobiotic and carcinogen metabolism. Toxicol In Vitro 20: 187-210

MUTOH M, TAKASHI M, FUKUDA K, KOMATSU H, ENYA T, MASUSHIMA- HIBIYA Y, MUTOH H, SUGIMURA T, WAKABAYASHI K (2000) Suppression by flavonoids of cyclooxygenase-2 promoter-dependent transcriptional activity in colon cancer cells: structure-activity relationship. J Cancer Res 91: 686-691

NEWAIRY AA, EL-SHARAKY AS, BADRELDEEN MM, EWEDA SM, SHEWEITA S (2007) The hepatoprotective effects of selenium against cadmium toxicity in rats. Toxicology 242: 23-30

OHINISHI M, MORISHITA H, IWAHASHI H, SHIZUO T, YOSHIAKI S, KIMURA M, KIDO R (1994) Inhibitory effects of chologenic acids on linoleic acid peroxidation and haemolysis. Phytochemistry 36: 579583

PAGILA DE, VALENTINE WN (1967) Studies on the quantitative and qualitative characterization of erythrocyte glutathione peroxidase. J Lab Clin Med 70: 158-169

RAZALI N, RAZAB R, JUNIT SN, AZIZ AA (2008) Radical scavenging and reducing properties of extracts of cashew shoots (Anacardium occidentale). Food Chem 111: 38-44

RAZINGER J, DERMASTIA M, KOCE JD, ZRIMEC A (2008) Oxidative stress in duckweed (Lemna minor L.) caused by short-term cadmium exposure. Environ Pollut 153: 687-694
RODRÍGUEZ-SERRANO M, ROMERO-PUERTAS MC, ZABALZA A, CORPAS FJ, GÓMEZ M, DEL RÍO LA, SANDALIO LM (2006) Cadmium effect on oxidative metabolism of pea (Pisum sativum L.) roots. Imaging of reactive oxygen species and nitric oxide accumulation in vivo. 1: Plant Cell Environ 29: 153244

SARKAR S, YADAV P, BHATNAGAR D (1998) Lipid peroxidative damage on cadmium exposure and alterations in antioxidant system in rat erythrocytes: a study with relation to time. Biometals 11: 153-157

SHAHIDI F, JANITHA PK, WANASUNDARA PD (1992) Phenolic antioxidants. Crit Rev Food Sci Nutr 32: 67103

SHANKAR S, GANAPATHY S, SRIVASTAVA RK (2007) Green tea polyphenols: biology and therapeutic implications in cancer, Front Biosci 12: 4881-4899

SHARMA A, SHARMA MK, KUMAR M. (2007): Protective Effect of Mentha piperita against ArsenicInduced Toxicity in Liver of Swiss Albino Mice. Basic Clin Pharmacol Toxicol., 100, 249-257

SHI H, SUI Y, WANG X, LUO Y, JI L (2005) Hydroxyl radical production and oxidative damage induced by cadmium and naphthalene in liver of Carassius auratus. Comp Biochem Physiol 140: 115-21

STEELE VE, KELLOFF GJ, BALENTINE D, BOONE CW, MEHTA R, BAGHERI D, SIGMAN CC, ZHU S, SHARMA S (2000) Comparative chemopreventive mechanisms of green tea, black tea and selected polyphenol extracts measured by in vitro bioassays. Carcinogenesis 21: 63-7

TIPOE GL, LEUNG T, HUNG M, FUNG M (2007) Green tea polyphenols as an anti-oxidant and antiinflammatory agent for cardiovascular protection, Cardiovasc. Hematol. Disord. Drug Targets 7: 135-44

VICENTE-SÁNCHEZ C., EGIDO J., SÁNCHEZGONZÁLEZ PD., PÉREZ-BARRIOCANAL F., LÓPEZ-NOVOA JM., MORALES AI (2008) Effect of the flavonoid quercetin on cadmium-induced hepatotoxicity. Food Chem Toxicol 46: 2279-87

VINA J, BORRAS C, GAMBINI J, SASTRE J, PALLARDO FV (2005) Why females longer than males ? Inportance of the upregulation of longevityassociated genes by oestrogenic compounds. FEBS lett 579: $2541-45$

WAISBERG M, JOSEPH P, HALE H, BEYERSMANN D (2003) Molecular and cellular mechanisms of cadmium carcinogenesis. Toxicology 192: 95-117

WÄTJEN W, HAASE H, BIAGIOLI M, BEYERSMANN D (2002) Induction of apoptosis in mammalian cells by cadmium and zinc. Environ. Health Perspect 110 : $865-7$

JAMSHIDZADEH A, NIKNAHAD H, FIROZABADI N (2008) Hepatoprotective effect of grape seed extract on rat liver. Toxicol Lett 180: 50-xx

SELMANOGLU G, KUS E, KILIC A, KOCKAYA AE, AKAY MT (2008) Evaluation of furan toxicity on liver and kidney in male rats. Toxicol Lett 180: 57-xx

ZEASHAN H, AMRESH G, SINGH S, RAO CV (2008) Hepatoprotective activity of Amaranthus spinosus in experimental animals. Food Chem Toxicol, in press 